\title{
EVALUASI PROGRAM KREDIT KOPERASI PRIMER ANGGOTA (KKPA) PT PERKEBUNAN NUSANTARA V
}

\author{
Dian Sari \\ Program Studi Teknik Informatika, FTMIPA \\ Universitas Indraprasta PGRI \\ Email: Diansari.unindra@gmail.com
}

\begin{abstract}
The evaluation of program Kredit Koperasi Primer Anggota (KKPA) PT Perkebunan Nusantara V (Case studies: KUD Hidup Baru in the Sungai Pagar District Kampar Kiri Hilir Subdistrict Kampar Regency) has problems such as being late on planting of the plantation, the payment credit of the first stage is unpaid on last 2011, the plantation in stage third is can not to harvest. These problems make me attract to do discuss in this research. The purpose of this research is to evaluate the program of KKPA PT Perkebunan Nusantara V (Case studies: KUD Hidup Baru in in the Sungai Pagar DistrictKampar Regency). The research use theory of David Easton (1984) about the policy as a process. Based on result of this research, $i$ can conclude that Input of program implementation has been corresponding with the demands of society and the support of government. The process of program has many problems such as first stage to second stage has been planting but it is too late, the distribution of areal first stage has been delayed, some groups of Sungai Pagar society claimed that area KKPA in second stage belogs to them, and area in third stage is often floaded. The condition area of first stage and second stage has good condition and productive, but the condition area of third stage is classified failed to harvests because the area that flooded and $75 \%$ palm plantation can not to harvest. The outcome had been accepted by member of KUD Hidup Baru, their income from selling $T B S$ in first stage and second stage. The impact from this program in society is changes of income, using of time, and educational needs increasingof prosperity in the society and there are job opportunities in program.
\end{abstract}

Keywords: Input, Process of Policy, Output, Outcome, Impact.

\begin{abstract}
ABSTRAK
Evaluasi Program Kredit Koperasi Primer Anggota (KKPA) PT Perkebunan Nusantara V (Studi Kasus KUD Hidup BARU di Kelurahan Sungai Pagar Kecamatan Kampar Kiri Hilir Kabupaten Kampar) terjadi beberapa masalah seperti terjadinya keterlambatan waktu penanaman, pembayaran kredit tahap I yang belum lunas pada akhir tahun 2011 dan lahan tidak produktif pada lahan tahap III. Hal inilah yang membuat saya tertarik untuk membahasnya dalam penelitian saya ini. Tujuan penelitian ini adalah untuk mengevaluasi program Kredit Koperasi Primer Anggota (KKPA) PT Perkebunan Nusantara V Kelurahan Sungai Pagar, Kecamatan Kampar Kiri Hilir, Kabupaten Kampar (Studi Kasus KUD Hidup Baru). Dalam penelitian ini menggunakan teori David Easton (1984) tentang kebijakan sebagai suatu proses. Berdasarkan hasil penelitian pada penelitian ini, dapat disimpulkan bahwa Input dalam pelaksanaan sudah sesuai dengan tuntutan masyarakat dan dukungan, proses pelaksanaan dari tahap I hingga tahap II terjadi keterlambatan penanaman satu hingga dua tahun, pelaksanaan terjadi permasalahan mulai dari pembagian lahan kepada masyarakat yang lambat oleh tim penjaringan. Kondisi lahan pada tahap I dan tahap II digolongkan baik dan produktif, namun pada kondisi lahan tahap III digolongkan gagal panen (puso) karena lahan digenangi banjir sehingga 75\% tanaman mati. Outcome sudah diterima oleh masyarakat berupa hasil tahap TBS tahap I dan tahap II. Dampak dalam masyarakat terjadi perubahan dalam hal pendapatan, pemanfaatan waktu, dan kebutuhan pendidikan.
\end{abstract}

Kata Kunci : Input, Proses Kebijakan, Output, Outcome, Dampak. 


\section{PENDAHULUAN}

Dampak reformasi yang begitu nyata terjadi di Provinsi Riau terkhusus di Kelurahan Sungai Pagar. Pada pertengahan tahun 1997 seorang transmigran dari kota Blitar yang sudah tinggal di Sungai Pagar sejak tahun 1984 mendapat tawaran kerjasama dan menandatangani kontrak kerjasama antara Perusahaan Kebun Sawit dengan Bank penyandang dana untuk membangun Kebun Kelapa Sawit dilahan seluas 7.500 Ha dan lahan cadangan dengan pola Kredit Koperasi Primer Anggota Primer (KKPA). KKPA adalah kredit investasi dan atau kredit modal kerja yang diberikan oleh Bank kepada Koperasi Primer untuk diteruskan kepada anggota-anggotanya guna membiayai usaha anggota yang produktif. Hal tersebut merupakan hasil Keputusan Bersama Menteri Pertanian dan Menteri Koperasi dan Pembinaan Pengusaha Kecil No.73/Kpts/KB.510/2/1998 dan No. 01/SKB/M/11/98 Tentang Pembinaan dan Pengembangan Koperasi Unit Desa di Bidang Usaha Perkebunan Dengan Pola Kemitraan Melalui Pemanfaatan Kredit Kepada Koperasi Primer untuk Anggotanya.

Hal ini mengakibatkan kesenjangan sosial antara masyarakat tempatan (penduduk asli) dengan masyarakat pendatang. Penduduk asli sungai pagar menuntut kepada salah satu perusahaan perkebunan kelapa sawit yang ada di sekitar kelurahan itu yaitu PT Perkebunan Nusantara V. Mereka menuntut agar dibuat lahan perkebunan kelapa sawit dengan pola KKPA (Kredit Koperasi Anggota Primer) di kelurahan mereka. Tuntutan tersebut berkembang menjadi aksi demonstrasi masyarakat Kelurahan Sungai Pagar pada tahun 1999. Aksi demostrasi berupa pendudukan areal di beberapa afdeling (afd II, III), penjarahan Tandan Buah Segar (TBS), dan menutup akses jalan ke kebun sehingga mengakibatkan produksi Crude Palm Oil (CPO) tidak dapat diangkut ke luar kebun. Maka untuk mengatasi keadaan ini, Pemerintah melalui PT Perkebunan Nusantara V berkerjasama dengan Bank untuk membangun kebun kelapa sawit dengan pola Kredit Koperasi Primer Anggota (KKPA).

Program ini telah terealisasi penggunaan kebun sebanyak 3 tahap dengan luas sebagai berikut: tahap I (150 Ha), tahap II (250 Ha), tahap III (200 Ha). Jadi jumlah seluruh lahan KKPA di

Kelurahan Sungai Pagar adalah 400 Ha. Lahan ini merupakan lahan yang disediakan oleh masyarakat penduduk asli, untuk lebih jelasnya dapat dilihat pada tabel (A.1). Setelah kebun sawit menghasilkan TBS, maka TBS tersebut harus dijual kepada PT Perkebunan Nusantara V, dan hasil penjualan TBS akan diberikan kepada masyarakat. Pada setiap bulan PT Perkebunan Nusantara $\mathrm{V}$ juga memberikan biaya untuk pemeliharaan kebun kelapa sawit tersebut agar produksi yang dihasilkan dapat tercapai dan dapat membayar hutang ke PT Perekebunan Nusantara V dan Bank, untuk lebih jelas dapat dilihat pada tabel (A.2).

Berdasarkan data pada tabel (A.2) dapat dilihat banyak permasalahan yang terjadi pada program mulai dari waktu penanaman yang terlambat satu hingga dua tahun, belum tercapainya pelunasan kredit pada tahap I, kesejahteraan masyarakat belum mencapai $100 \%$, dan kondisi lahan tahap III yang $100 \%$ digolongkan tidak produktif. Berdasarkan fenomena tersebut, maka peneliti membuat rumusan masalah yaitu bagaimana pelaksanaan program Kredit Koperasi Primer Anggota (KKPA) PT Perkebunan Nusantara V Kelurahan Sungai Pagar, Kecamatan Kampar Kiri Hilir, Kabupaten Kampar (Studi Kasus KUD Hidup Baru). Tujuan yang hendak dicapai dalam penelitian ini adalah untuk mengevaluasi Program Kredit Koperasi Primer Anggota (KKPA) PT Perkebunan Nusantara V Kelurahan Sungai Pagar, Kecamatan Kampar Kiri Hilir, Kabupaten Kampar (Studi Kasus KUD Hidup Baru).

\section{METODE}

Lokasi penelitian bertempat di desa Sungai Pagar (Koperasi Hidup Baru), kecamatan Kampar Kiri Hilir, Provinsi Riau. Lokasi kebun kelapa sawit pola KKPA seluas $400 \mathrm{Ha}$. Jenis penelitian menggunakan pendekatan kualitatif. Peneliti memperoleh data langsung secara pribadi ke lapangan melalui wawancara dan memperoleh data dengan menggunakan kuesioner terbuka dan tertutup yang telah disusun terlebih dahulu dan sekaligus disebarluaskan kepada sejumlah besar sample yang representatif yaitu petani peserta KKPA PT Perkebunan Nusantara V di Kelurahan Sungai Pagar KUD Hidup Baru. Metode yang dilakukan dalam penelitian ini adalah dengan menggunakan metode penelitian evaluasi. Subjek 
penelitian ini adalah petani peserta KKPA PT Perkebunan Nusantara V di Kelurahan Sungai Pagar KUD Hidup Baru, Pegawai Perkebunan Nusantara V Kebun Sungai Pagar, dan pegawai Perkebunan Nusantara V kantor pusat. Pada penelitian ini menggunakan teknik sampling snowball sampling. Snowball sampling dimulai dari Asisten urusan KKPA/Plasma di Kantor Pusat PT Perkebuna Nusantara V, kemudian kepada Asissten Kepala dan Asisten Afdeling PT Perkebunan Nusantara V Kebun Sungai Pagar, dan petani peserta anggota KKPA.

\section{HASIL DAN PEMBAHASAN}

Evaluasi program Kredit Koperasi Primer Anggota (KKPA) PT Perkebunan Nusantara V di Kelurahan Sungai Pagar Kecamatan Kampar Kiri Hilir Kabupaten Kampar (KUD HIDUP BARU) dilakukan dengan menggunakan lima indikator dalam mengevaluasi yaitu input, proses kebijakan, output, outcome, dan dampak.

1. Input

Input terdiri dari atas pelayanan yang layak, penghasilan yang layak, dan kehidupan yang layak.

\subsection{Pelayanan yang layak}

Pelayanan yang layak berupa pelayanan pemberian kredit lahan kebun kelapa sawit di Kelurahan Sungai Pagar kepada KUD Hidup Baru dengan pola Kredit Koperasi Primer Anggota (KKPA) seluas dua Hetarare per KK. 62 responden dengan persentase 92,54\% menyatakan bahwa program KKPA sudah sesuai dengan tuntutan masyarakat yaitu mendapatkan pelayanan yang layak. Pelayanan yang layak berupa pemberian kredit lahan kebun kelapa sawit di Kelurahan Sungai Pagar pada KUD Hidup Baru dengan pola Kredit Koperasi Primer Anggota (KKPA) seluas dua Hetarare per KK.

\subsection{Penghasilan yang layak}

Hasil yang diperoleh Anggota KUD Hidup Baru diharapkan dapat memenuhi kebutuhan hidup anggota KUD sehari-hari. Hasil yang diperoleh mencakup kepada standar UMK (Upah Minimum Kabupaten) Kampar pada tahun 2011 yaitu sebesar Rp 1.234.000/bulan. Sebanyak 53 responden dengan persentase $79,1 \%$ anggota KUD Hidup Baru sudah memiliki pendapatan di atas UMK Kampar, hal ini juga membuktikan melalui program KKPA PT Perkebunan Nusantara V di Kelurahan Sungai Pagar sudah dapat meningkatkan pendapatan masyarakat dan dapat digolongkan masyarakat mampu. Jadi program KKPA PT Perkebunan Nusantara V Kelurahan Sungai Pagar pada KUD Hidup Baru sudah sesuai dengan tuntutan masyarakat yaitu mendapatkan penghasilan yang layak yaitu lebih dari Rp 1.234.000/bulan diatas UMK Kampar.

\subsection{Kehidupan yang layak}

Kehidupan yang layak adalah terpenuhinya kebutuhan sandang, pangan dan papan. Sebanyak $100 \%$ responden menjawab bahwa program KKPA ini sudah memenuhi kebutuhan mereka, baik sandang, pangan, maupun papan. Jadi tujuan untuk memenuhi kebutuhan hidup yang layak sesuai dengan tuntutan dapat terpenuhi. Berdasarkan Rekapitulasi tanggapan responden tentang input program yang ditinjau berdasarkan tuntutan masyarkat berupa pelayanan yang layak, penghasilan yang layak, kehidupan yang layak, maka diketahui hasil tanggapan responden yaitu 60 responden menjawab bahwa program KKPA PT Perkebunan Nusantara V Kelurahan Sungai Pagar pada KUD Hidup Baru sudah berdasarkan tuntutan masyarakat berupa pelayanan yang layak, penghasilan yang layak, dan kebutuhan yang layak.

\section{Proses Kebijakan}

\subsection{Program KKPA Tahap I}

2.1.1.Penggunaan Dana

Dana berasal dari PT Perkebunan Nusantara V yang merupakan sebagai penjamin (avalist) dalam melakukan penanaman, pembelian bibit, pemeliharaan lahan dan biaya-biaya lain yang dianggap penting dalam program KKPA dan juga suku bunga KKPA dan pembayaran kredit oleh petani peserta. Biaya tersebut kemudian dibayar oleh petani peserta atau anggota KUD Hidup Baru melalui hasil penjualan TBS. Sebanyak $100 \%$ responden menjawab bahwa penggunaan dana dalam pelaksanaan program KKPA PT perkebunan Nusantara V di Kelurahan Sungai Pagar sesuai dengan ketentuan yang berlaku yaitu penggunaan dana dalam pelaksanaan program KKPA ini dimulai dengan adanya jaminan dari PT Perkebunan Nusantara V yang berkerjasama dengan Bank Agro sebagai Bank pelaksana dalam program ini. Suku bunga KKPA adalah $17 \%$ per tahun. Suku bunga tersebut dibayarkan oleh petani sebanyak 30\% dari suku bunga tersebut, pembayaran dilakukan dengan penjualan hasil TBS kepada PT Perkebunan Nusantara V kemudian dipotong biaya-biaya yang menyangkut pemiliharaan lahan setelah itu dipotong dengan hutang pokok petani peserta, namun apabila produktivitas menurun maka 
pihak PT Perkebunan Nusantara V yang menanggulangi hutang yang di bayar ke Bank Agro. Apabila Koperasi bertindak sebagai penyalur KKPA dan lancar dalam pemberian kredit, maka dari imbalan sebesar 2\% tersebut hanya diberikan kepada koperasi sebesar 50\%nya atas dasar realisasi pembayaran angsuran pokok dan bunganya oleh anggota koperasi yang memperoleh KKPA, dan sisanya 50\% lagi menjadi penerimaan bank."

\subsubsection{Penggunaaan waktu penanaman program} KKPA tahap I

Penggunaan waktu penanaman dimulai pada tahun 2000 dan 2001. Sebanyak 53 responden dengan persentase $79,10 \%$ menyatakan bahwa penggunaan waktu dalam program KKPA PT Perkebunan Nusantra V Kelurahan Sungai Pagar pada KUD Hidup Baru sudah sesuai dengan perencanaan yaitu dimulai pada tahun 2000 dan 14 responden menyatakan bahwa penggunaan waktu dalam program KKPA PT Perkebunan Kelurahan Sungai Pagar pada KUD Hidup Baru dilakukan tidak sesuai dengan perencanaan karena mengalami keterlambatan satu sampai dua tahun dalam pelaksanaan program.

\subsubsection{Pelaksanaan program KKPA PT} Perkebunan Nusantara V Kelurahan Sungai Pagar pada KUD Hidup Baru Tahap I

Sebanyak 43 atau 64,18\% responden anggota KUD hidup baru menyatakan bahwa permasalahan yang terjadi adalah pembagian lahan KKPA tahap I kepada calon petani oleh tim penjaringan yang lambat dan masyarakat mengganggap tim penjaringan tidak adil dalam memilih masyarakat yang berhak ikut dalam program ini. Pembagian lahan KKPA tahap I kepada KUD Hidup Baru hanya anggapan bersifat individu saja, karena tim penjaringan lebih mengetahui siapa yang berhak ikut dalam program ini dengan melihat dari keadaan ekonomi masyarakat.

\subsection{Program KKPA Tahap II}

\subsubsection{Penggunaan waktu penanaman program} KKPA tahap II.

Penggunaaan waktu penanaman dan pelaksanaan program KKPA tahap II dimulai pada tahun 2003 dan 2004. Sebanyak 53 responden dengan persentase $79,10 \%$ menjawab bahwa penggunaan waktu dalam program KKPA PT perkebunan Nusantara V Kelurahan Sungai Pagar pada KUD Hidup Baru dimulai pada tahun 2004 dan 14 responden dengan persentase $20,90 \%$ memberi tanggapan bahwa penggunaan waktu dalam program KKPA PT Perkebunan Nusantara V Kelurahan Sungai Pagar pada KUD Hidup Baru tahap II tidak sesuai dengan perencanaan karena mengalami keterlambatan satu sampai dua tahun dalam pelaksanaan program.

\subsubsection{Pelaksanaan program KKPA PT} Perkebunan Nusantara V Tahap II di Kelurahan Sungai Pagar.

Sebanyak 41 atau 64,18\% responden Anggota KUD Hidup Baru memberikan tanggapan bahwa ada terjadi permasalahan dalam tahap II yaitu sengketa lahan atau pengakuan kepemilikan lahan oleh masyarakat setempat. Permasalahan yang terjadi di Tahap II sudah lama terjadi sekitar pada awal penanaman yaitu sekitar tahun 2004. Permasalahan pada waktu itu ialah adanya sekelompok masyarakat setempat yang merasa 12 Hektar lahan KKPA adalah lahan miliknya, namun masalah ini tidak berlangsung panjang karena sekelompok masyarakat tersebut tidak dapat memberikan bukti mengenai keabsahan tanah tersebut miliknya dan diselesaikan dengan musyawarah dibantu oleh Ninik Mamak masyarakat setempat."

\subsection{Program KKPA Tahap III}

2.3.1. Penggunaan waktu penanaman program KKPA tahap III.

Tahap III dimulai pada tahun 2006 hingga 2009. Sebanyak 44 responden dengan persentase $65,67 \%$ responden memberi tanggapan bahwa penggunaan waktu dalam pelaksanaan KKPA PT Perkebunan Nusantara V Kelurahan Sungai Pagar pada KUD Hidup Baru tahap III sesuai dengan perencanaan dan 23 responden dengan persentase $34,33 \%$ responden menjawab bahwa penggunaan waktu dalam pelaksanaan KKPA PT Perkebunan Nusantara V Kelurahan Sungai Pagar pada KUD Hidup Baru tahap III tidak sesuai dengan perencanaan. Responden menjawab tidak sesuai dengan perencanaan dikerenakan adanya keterlambatan.

\subsubsection{Pelaksanaan program KKPA PT} Perkebunan Nusantara V Tahap III di Kelurahan Sungai Pagar .

Tahap III merupakan tahap terkahir pelaksanaan program KKPA PT Perkebunan Nusantara V di Kelurahan Sungai Pagar. Tahap III ini pada bulan april 2011 pemeliharaannya telah diberhentikan karena banjir yang menggenangi lahan sehingga penanaman yang telah dilakukan dari tahun 2006 diperkiran $75 \%$ mati. Hal tersebut dikarenakan 
lahan digenangi banjir karena berada diantara dua sungai, sehingga luapan air sungai yang mengakibatkan banjir. Pada Oktober 2010 PT Perkebunan Nusantara V mengundang tim dari Fakultas Pertanian Universitas Sumatera Utara ( USU) untuk mengadakan studi kelayakan pada areal ini, namun hasil yang didapat dari hasil penelitian USU kurang memuaskan pihak PT Perkebunan Nusantara V karena kurang menjamin keberhasilan dilakukan penanaman lagi apabila melakukan saran dari penelitian mereka. Pada 19 September 2011 Pihak PT Perkebunan Nusantara V kembali mengundang pihak akademis, yaitu dari Fakultas Pertanian Universitas Riau (UR) dan hasilnya dikeluarkan pada akhir Desember 2011, yang menyimpulkan bahwa lahan tahap III program KKPA PT Perkebunan Nusantara V di Kelurahan Sungai Pagar tidak dapat dilanjutkan untuk digunakan sebagai perkebunan kelapa sawit namun lebih cocok dialihkan untuk dijadikan peternakan. Jadi lahan di tahap III adalah lahan gagal panen (puso). Kesimpulan tersebut belum direalisasikan karena belum dipresentasikan kepada komisaris PT Perkebunan Nusantara V pada taun 2011." (hasil wawancara pada tanggal 12 Januari 2012)

\section{Output}

Output pada penelitian ini adalah hasil program KKPA PT Perkebunan Nusantara V di Kelurahan Sungai Pagar pada KUD Hidup Baru yang ditinjau dari:

\subsection{Pembagian hasil kepada masyarakat}

Sebanyak $100 \%$ responden menyatakan hasil yang diperoleh masyarakat sesuai dengan perjanjian pembuatan kebun kelapa sawit pola KKPA yaitu mendapat pembagian dari hasil penjualan TBS dikurangi dengan hutang pokok peserta kepada PT Perkebunan Nusantara V dalam pembangunan kebun kelapa sawit Pola KKPA dan biaya pemeliharaan.

\subsection{Hasil penjualan TBS tahap I}

Sebanyak 57 atau $85,07 \%$ responden menyatakan perolehan hasil penjualan TBS tahap I dapat meningkatkan pendapatan peserta tani dan meningkatkan kesejahteraan anggota KUD Hidup Baru. Penjualan TBS tahap I dapat meningkatkkan kesejahteraan sehingga tahap I dikategorikan berhasil.

\subsection{Hasil penjualan TBS tahap II}

Sebanyak 64 responden dengan persentase 95,52\% menyataan perolehan hasil dalam pelaksanaan program KKPA PT Perkebunan Nusantara V pada tahap II ini telah dapat meningkatkan pendapatan peserta tani. Jika dibandingkan dengan hasil pada perolehan hasil penjualan TBS pada tahap I didapatkan data bahwa responden lebih banyak setuju bahwa program KKPA tahap II lebih digolongkan berhasil karena lebih dapat memecahkan masalah kesejahteraan dan meningkatkan pendapatan peserta tani daripada hasil penjualan tahap I. Hasil penjualan TBS tahap I lebih rendah dibandingkan hasil penjualan TBS tahap II karena harga TBS pada pemanenan pernah mengalami harga yang sangat rendah yaitu Rp 700 per Kilogram.

\section{Outcome}

Outcome adalah hasil suatu kebijakan dalam jangka waktu tertentu sebagai akibat diimplementasikan suatu kebijakan. Outcome pada penelitian ini berupa keluaran dari program KKPA PT Perkebunan Nusantara V di Kelurahan Sungai Pagar Pada KUD Hidup Baru. Pada hal ini hanya ditinjau dari penggunaan waktu pembayaran kredit Tahap I , karena tahap I direncanakan akan lunas tahun 2011, sedangkan tahap II dan tahap III belum dapat diketahui. Hal ini dimaksudkan untuk mengetahui apakah petani sudah mendapat haknya menjadi pemilik lahan dua Hektarare lahan kelapa sawit yang sudah memiliki hasil. Untuk mengetahui lebih jelas, dapat dilihat dibawah ini:

4.1. Penggunaan waktu pelunasan kredit tahap I.

Pembayaran kredit tahap I ditargetkan akan lunas pada akhir tahun 2011, sebanyak 61 atau $91,04 \%$ responden menyatakan penggunaan waktu pelunasan kredit tahap I tidak sesuai dengan perencanaan pelunasan kredit dalam program KKPA PT Perkebunan Nusantara V yang direncanakan lunas pada akhir tahun 2011 karena pelunasan kredit tahap I diperkirakan akan selesai pada akhir tahun 2012 atau akhir tahun 2013 sehingga petani belum bisa menjadi pemilik sah dari lahan 2 hektar kebun kelapa sawit yang sudah menghasilkan tersebut. Hal tersebut dikarenakan masyarakat tidak bisa melunasi pembayaran kredit tahap I sesuai dengan target sebab harga TBS kelapa sawit yang tidak stabil bahkan hingga mencapai harga yang sangat rendah yaitu Rp 700 per Kilogram. Jadi outcome pelaksanaan program KKPA PT perkebunan Nusantara V di Kelurahan Sungai Pagar Kecamatan Kampar Kiri Hilir Kabuapaten Kampar (Studi Kasus KUD Hidup Baru) pada 
tahun 2011 belum dapat diterima oleh anggota KUD Hidup Baru. Keterlambatan pembayaran ini membuat masyarakat menunda dulu untuk menjadi pemilik sah lahan perkebunan kelapa sawit dengan pola KKPA yang sudah menghasilkan tersebut dan membuat ketidakefesienan dalam pengeluaran biaya, karena keterlambatan ini membuat masyarakat tetap membayar bunga kepada Bank.

\section{Dampak}

Dampak adalah akibat lebih jauh pada masyarakat sebagai konsukuensi adanya pelaksanaan program KKPA PT Perkebunan Nusantara V di Kelurahan Sungai Pagar pada KUD Hidup Baru Dampak melihat perubahan yang terjadi pada masyarakat akibat pelaksanaan program KKPA ini, hal ini dilihat dari perubahan:

\subsection{Pendapatan}

Pendapatan adalah hal penting dan yang dicari anggota KUD Hidup Baru dari pelaksanaan program ini, terjadi perubahan pendapatan. Di dalam kuesioner, rata-rata responden memiliki pendapatan kurang dari $\mathrm{Rp} 1.000 .000 /$ bulan sebelum ikut dalam program ini setelah mengikuti program KKPA PT Perkebunan Nusantara V Kelurahan Sungai Pagar Kabupaten Kampar, pendapatan mereka meningkat menjadi lebih dari Rp 1.500.000/bulan.

\subsection{Kebutuhan Pendidikan}

Kebutuhan pendidikan bagi anggota KUD sebelum dan setelah ikut dalam program KKPA PT Perkebunan Nusantara V Kelurahan Sungai Pagar Kabupaten Kampar diketahui bahwa 50 responden dengan persentase $74,63 \%$ responden menyatakan bahwa program KKPA PT Perkebunan Nusantara V Kelurahan Sungai Pagar Kabupaten Kampar dapat memampukan anggota KUD Hidup Baru meningkatkan pendidikan anak mereka. Sebanyak 50 responden menjawab setuju, 15 responden menjawab dahulu hanya mampu menyekolahkan anaknya hingga SMA sekarang dapat menyekolahkan anaknya hingga ke Perguruan Tinggi, 18 responden menjawab dahulu hanya bisa menyekolahkan anaknya hingga SMP sekarang sudah bisa hingga SMA, dan 18 responden menjawab dahulu tidak bisa menyekolahkan anaknya sekarang sudah bisa menyekolahkan anaknya hingga SMA.

Berdasarkan Rekapitulasi jawaban responden tentang dampak program KKPA PT perkebunan
Nusantara V (Studi Kasus KUD Hidup Baru di Kelurahan Sungai Pagar Kecamatan Kampar Kiri Hilir Kabuapaten Kampar) yang ditinjau dari sub indikator yaitu perubahan pendapatan, dan perubahan kebutuhan pendidikan. Hasil jawaban responden yaitu 62 responden menyatakan bahwa dampak dari program KKPA PT perkebunan Nusantara V di Kelurahan Sungai Pagar sangat dirasakan masyarakat terkhususnya bagi anggota KUD Hidup Baru, seperti perubahan pendapatan, dan perubahan kebutuhan pendidikan. Dampak yang terjadi ini membuat keefesienan anggota KUD hidup baru, sehingga mengurangi pengangguran, mengurangi banyaknya penduduk setempat yang mencari pekerjaan keluar daerah, dan membuat semakin berkualitasnya SDM masyarakat setempat karena dapat menyekolahkan anaknya.

Pelaksanaan Program Kredit Koperasi Primer Anggota (KKPA) PT Perkebunan Nusantara V di Kelurahan Sungai Pagar, Kabupaten Kampar (Studi: KUD Hidup Baru) telah melakukan pelaksanaan yang sesuai dengan buku pedoman bagi koperasi dalam melaksanakan nilai-nilai koperasi dalam praktek. Temuan dari beberapa penelitian menyatakan program KKPA PT Perkebunan Nusantara V di Kelurahan Sungai Pagar, Kabupaten Kampar (Studi: KUD Hidup Baru) dapat mencapai tujuan program untuk mensejahterahkan petani dan masyarakat transmigran di lingkungan sekitar perusahaan. Namun dalam penelitian (Akbar Perdana;2008) disarankan perlu adanya penyuluhan. Materi Pembinaan dan penyuluhan yang diberikan disaranakan adalah sistem pemeliharaan dan pemanenan tanaman kelapa sawit. Tenaga pembinaan dan penyuluhan adalah mandormandor dari pihak inti perusahaan. Mandormandor tersebut berperan sebagai tenaga ahli dalam bidang sistem pemeliharaan dan pemanenan tanaman kelapa sawit.

Kemitraan pola KKPA merupakan pola kemitraan perusahaan inti dan petani dalam wadah koperasi untuk meningkatkan daya guna lahan petani peserta dalam usaha meningkatkan pendapatan dan kesejahteraan anggota melalui kredit jangka panjang dari bank. Selama proses ini, koperasi sebagai wadah petani berhak untuk melakukan pengawasan pada perusahaan inti. Perusahaan membangun dan mengelola kebun KKPA berdasarkan memorandum of understanding pengelolaan kebun antara inti dan KUD sampai batas waktu tertentu. Pola kerja 
samanya adalah konversi hasil, yakni kebun dikelola perusahaan dan petani menerima bagi hasil. Untuk menjaga transparansi di KKPA, maka dilibatkan unsur petani dari KUD. Koperasi petani yang mengelola perkebunan kelapa sawit rakyat adalah koperasi primer yang telah berbadan hukum sebagaimana diatur oleh UndangUndang Nomor 25 Tahun 1992 tentang Perkoperasian. Program KKPA dapat berlangsung secara optimal apabila didukung oleh strategi yang tepat dan komitmen yang kuat, seperti perusahaan menyediakan dana untuk mendukung kegiatan sesuai dengan kebutuhan di lapangan, dan keterlibatan pimpinan dan karyawan perusahaan dalam pelaksanaan program dalam penyelesaian sengketa lahan dilakukan di luar pengadilan dengan menggunakan metode konsultasi, mediasi, konsiliasi, atau penilaian ahli.

\section{SIMPULAN DAN SARAN}

Berdasarkan hasil yang diperoleh dari hasil dan pembahasan tentang Evaluasi Program Kredit Koperasi Primer Anggota (KKPA) PT Perkebunan Nusantara V pada studi KUD Hidup Baru di Kelurahan Sungai Pagar Kecamatan Kabupaten Kampar, maka dapat disimpulkan bahwa Program KKPA PT Perkebunan Nusantara V pada studi KUD Hidup Baru di Kelurahan Sungai Pagar Kecamatan Kabupaten Kampar sudah berdasarkan tuntutan masyarakat berupa pelayanan yang layak, penghasilan yang layak, kebutuhan yang layak, dan dukungan yang berupa hasil merupakan hasil Keputusan Bersama Menteri Pertanian dan Menteri Koperasi dan Pembinaan Pengusaha Kecil No.73/Kpts/KB.510/2/1998 dan No. 01/SKB/M/11/98 Tentang Pembinaan dan Pengembangan Koperasi Unit Desa di Bidang Usaha Perkebunan Dengan Pola Kemitraan Melalui Pemanfaatan Kredit Kepada Koperasi Primer untuk Anggotanya. Program KKPA ini juga sudah memberikan pelayanan yang layak berupa pemberian kredit lahan kebun kelapa sawit dengan pola KKPA seluas dua Hektarare per KK, penghasilan yang layak berupa penghasilan diatas UMK Kampar yaitu lebih dari Rp 1.234.000, kebutuhan hidup yang layak yaitu anggota KUD Hidup Baru sudah dapat memenuhi kebutuhan sandang, pangan, dan papan. Program Kredit Koperasi Primer Anggota (KKPA) PT Perkebunan Nusantara V di Kelurahan Sungai Pagar Kecamatan Kabupaten Kampar pada studi KUD Hidup Baru dalam hal penggunaan dana sangat jelas, tahap I hingga tahap III mengalami keterlambatan waktu penanaman satu hingga dua tahun, pelaksanaan pada tahap I hingga tahap III mengalami permasalahan, pada tahap I dan tahap II permasalahan tidak begitu berarti dan mampu member output kepada anggota KUD Hidup Baru, namun permasalahan pada tahap III tidak dapat mengahasilkan output karena lahan digenangi banjir.

Output dalam hal pembagian hasil sudah sesuai dengan ketentuan, hasil penjualan tahap I dan tahap II sudah dapat dinikmati anggota KUD Hidup Baru. Outcome yang berupa pelunasan kredit tahap I mengalami keterlambatan pelunasan yang direncanakan akan lunas akhir tahun 2011 tapi tidak dapat tercapai dan lahan seluas dua Hekatrare yang sudah mengahasilkan belum dapat diberikan sepenuhnya pada Anggota KUD Hidup Baru.Dampak yang diterima masyarakat adalah terjadi perubahan dalam hal pendapatan yang meningkat, perubahan pemanfaatan waktu sehingga anggota KUD dan masyarakat di Kelurahan Sungai Pagar lebih banyak bekerja daripada menganggur, dan pemanfaatan kebutuhan pendidikan sehingga anggota KUD sudah bisa menyekolahkan anknya hingga ke perguruan tinggi dan SMA.

Jadi secara keseluruhan program Kredit Koperasi Primer Anggota (KKPA) PT Perkebunan Nusantara V Kelurahan Sungai Pagar Kabupaten Kampar (Studi Kasus KUD Hidup Baru) sudah berjalan dengan baik dan sudah mencapai tujuan yang telah ditentukan yaitu untuk meningkatkan penghasilan dan pendapatan petani peserta melalui pengembangan dibidang usaha perkebunan, meningkatkan usaha KUD melalui hubungan kemitraan dan menumbuh kembangkan peran dan fungsi KUD.

Berdasarkan kesimpulan terhadap Evaluasi Program Kredit Koperasi Primer Anggota (KKPA) PT Perkebunan Nusantara V di Kelurahan Sungai Pagar Kecamatan Kampar Kiri Hilir Kabupaten Kampar pada studi kasus KUD Hidup Baru diatas maka dapat disarankan program pembinaan dan pengembangan KUD (Koperasi Unit Desa) di bidang usaha perkebunan dengan pola kemitraan melalui pemanfaatan kredit kepada koperasi primer dapat dilaksanakan kembali oleh BUMN atau BUMD lainnya, hal itu dikarenakan Provinsi Riau memiliki banyak lahan yang potensial untuk dijadikan lahan perkebunan kelapa sawit 
sehingga semakin membuat banyak masyarakat di Provinsi Riau semakin sejahtera, dan meningkatnya usaha KUD melalui hubungan kemitraan.

Selanjutnya disarankan agar dalam pelaksanaan kembali program KKPA lahan perkebunan kelapa sawit supaya dapat membuat perencanaan dengan baik sehingga hasil yang dicapai sesuai dengan perencanaan yang dibuat, lebih memperhatikan mekanisme pembagian lahan, memperhatikan kepemilikan lahan, dan memperhatikan kondisi lahan. Sebab kondisi lahan hal yang sangat penting dalam perkebunan kelapa sawit agar tidak terjadi lagi permasalahan pada tahap III program KKPA PT Perkebunan Nusantara V di kelurahan Sungai Pagar yang dikarenakan kelalaian PT Perkebunan Nusantara $\mathrm{V}$ dalam melihat kondisi lahan dan tidak dapat memproyeksikan kondisi kedepannya. Kondisi lahan dapat diperhatikan dengan mengadakan peninjauan terlebih dahulu oleh para ahli perkebunan kelapa sawit.

Kemudian disarankan memberi pelatihan kepada pemanen dan pemupuk agar TBS yang dihasilkan maksimal dan dapat mempercepat pelunasan pembayaran kredit sehingga anggota KUD hidup Baru juga dapat mempercepat kepemilikan lahan yang sudah menghasilkan seluas dua Hektarare. Jadi program pembinaan dan pengembangan KUD (Koperasi Unit Desa) di bidang usaha perkebunan dengan pola kemitraan melalui pemanfaatan kredit kepada koperasi primer untuk anggotanya seperti program Kredit Koperasi Primer Anggota (KKPA) PT Perkebunan Nusantara V Kelurahan Sungai Pagar Kabupaten Kampar dapat dikembangkan lagi diseluruh Indonesia.

Tabel A.1 Program KKPA PT Perkebunan Nusantara V di Kelurahan Sungai Pagar

\begin{tabular}{cccc}
\hline Tahap & Tahun & Luas Lahan & Jumlah KK \\
\hline 1 & 2000 & $150 \mathrm{Ha}$ & $75 \mathrm{KK}$ \\
2 & 2004 & $250 \mathrm{Ha}$ & $125 \mathrm{KK}$ \\
3 & 2006 & $200 \mathrm{Ha}$ & \\
\end{tabular}

Sumber: PT Perkebunan Nusantara V, tahun 2011.

Tabel A.2 :Evaluasi Prograam KKPA PT Perkebunan Nusantara V di Kelurahan Sungai Pagar

\begin{tabular}{|c|c|c|c|}
\hline Tahap 1 & Perencanaan & Hasil & $\%$ \\
\hline Penanaman & $\begin{array}{l}\text { Tahun } 2000 \\
\text { hingga } 2001\end{array}$ & $\begin{array}{c}\text { Tahun } 2000 \text { sampai dengan } \\
2002\end{array}$ & $\begin{array}{lr}25 \% \text { penanaman } & \text { pada } \\
\text { tahun 2000, } & 75 \% \\
\text { penanaman pada } & \text { tahun } \\
\text { 2001 s/d 2002 } & \\
\end{array}$ \\
\hline $\begin{array}{l}\text { Pelunasan } \\
\text { Pembayaran } \\
\text { Kredit }\end{array}$ & Akhir tahun 2011 & $\begin{array}{l}\text { Akhir tahun } 2011 \\
\text { pembayaran kredit belum } \\
\text { lunas }\end{array}$ & $\begin{array}{l}0 \% \text { KK belum melunasi } \\
\text { pembayaran kredit pada } \\
\text { tahap I }\end{array}$ \\
\hline $\begin{array}{c}\text { Peningkatan } \\
\text { Pendapatan }\end{array}$ & $\begin{array}{l}75 \mathrm{KK} \text { meningkat } \\
\text { pendapatannya }\end{array}$ & $\begin{array}{l}63 \text { KK meningkat } \\
\text { pendapatannya }\end{array}$ & $\begin{array}{l}\text { Program ini dapat } \\
\text { mensejahterakan } \\
\text { anggota KUD Hidup Baru }\end{array}$ \\
\hline \multicolumn{4}{|l|}{ Tahap II } \\
\hline Penanaman & Tahun 2004 & Tahun 2004 dan 2005 & $\begin{array}{l}30 \% \text { penanaman } \\
\text { tahun } 2004, \text { dan } \\
\text { penanaman pada tahun } \\
\text { 2005. }\end{array}$ \\
\hline
\end{tabular}




\begin{tabular}{|c|c|c|c|}
\hline $\begin{array}{c}\text { Peningkatan } \\
\text { Pendapatan }\end{array}$ & $\begin{array}{l}125 \mathrm{KK} \\
\text { meningkat } \\
\text { pendapatannya }\end{array}$ & $\begin{array}{l}119 \text { KK meningkat } \\
\text { pendapatannya }\end{array}$ & $\begin{array}{l}\text { Mensejahterakan 95,52\% } \\
\text { anggota KUD Hidup Baru } \\
\text { tahap II. }\end{array}$ \\
\hline \multicolumn{4}{|l|}{ Tahap III } \\
\hline Penanaman & Tahun 2006 & Tahun 2006 dan 2007 & $\begin{array}{l}30 \% \text { penanaman dimulai } \\
\text { pada tahun } 2006 \text { dan } 70 \% \\
\text { penanaman dimulai pada } \\
\text { tahun } 2007 \text {. }\end{array}$ \\
\hline $\begin{array}{c}\text { Peningkatan } \\
\text { Pendapatan }\end{array}$ & Tidak terlaksana & Tidak Terlaksana & $\begin{array}{lrr}100 \% \text { lahan } & \text { tidak } \\
\text { produktif dan } & 75 \% \\
\text { tanaman mati. } & \end{array}$ \\
\hline
\end{tabular}

\section{Sumber: PT Perkebunan Nusantara V, Tahun 2011.}

\section{DAFTAR RUJUKAN}

Antina, Nevi. 2009. Evaluasi Program. http://www. Google.com, diakses tanggal 17 Desember 2010.

Bungin, Burhan. 2010. Metodologi Penelitian Kuantitatif. Jakarta: Kencana.

Dunn,William N. 2003. Analisis Kebijaksanaan Publik. Yogyakarta: Hanindita Graha Widya.

Indrawati, Henny. 2011. Kajian Tentang Hubungan Strategis Produsem Kelapa Sawit di Kabupaten Pelalawan Provinsi Riau. Pekbis Jurnal Volume 3 Nomor 2.

Nawawi, Ismail.2007. Public Policy. Surabaya: Pmn.

Nugroho,Riant. 2009. Public Policy. Jakarta: PT Elex Media Komputindo.

Perdana, Akbar. 2008. Dampak Pelaksanaan Program Kredit Kepada Koperasi Primer
Untuk Anggotanya (KKPA) Terhadap Pendapatan Usaha Kelapa Sawit. Bogor: Program Sarjana Ekstensi Manajmen Agribisnis Fakultas Pertanian Institut Pertanian Bogor.

Subarsono.2009. Analisis Kebijakan Publik. Yogyakarta: Pustaka Pelajar.

Suwandi, dkk.2013.Praktik Tanggung Jawab Sosial Perusahaan PT.Bakrie Sumatra Plantations (TBK) Unit Jambi. Kawistara Volume 3 Nomor 2.

Peraturan Bank Indonesia Nomor 6/26/PBI/2004. Keputusan Bersama Menteri Pertanian dan Menteri Koperasi dan Pembinaan Pengusaha Kecil No.73/Kpts/KB.510/2/1998 dan No. 01/SKB/M/11/98 Tentang Pembinaan dan Pengembangan Koperasi Unit Desa di Bidang Usaha Perkebunan Dengan Pola Kemitraan Melalui Pemanfaatan Kredit Kepada Koperasi Primer untuk Anggotanya. 